\title{
A FOSSIL GENUS OF DINAPSID E FROM BALTIC AMBER (HYMENOPTERA)
}

Contribution from the Entomological Laboratory of the Bussey Institution, Harvard University, No. 22C.

\section{By Charles T. Brues.}

A small lot of amber insects which I have had for a number of years contains a very extraordinary hymenopterous insect. Several times I have attempted to locate it in one of the recognized families of the order, but I have never been satisfied with the result. It has also been shown to a number of entomologists, none of whom were willing to express any positive opinion concerning its relationships. Several weeks ago it was sent to the hymenopterists of the United States National Museum with a request that they examine it, and I soon received a note from Mr. R. A. Cushman calling my attention to a paper by Dr. James Waterston just received in the current October number of the Annals and Magazine of Natural History wherein he describes an almost exactly similar living insect from South Africa. For the African form Waterston has proposed the genus Dinapsis which he makes the type of a new family, Dinapsidæ. He regards Dinapsis as more closely related to Megalyra than to any known Hymenoptera and from an examination of the fossil insect it seems that he is quite justified in expressing this opinion. Dinapsis is known only from the female, while the amber species is represented only by the male, but the two differ so clearly in wing venation and in the structure of the head and thorax that they cannot be regarded as congeneric. As the amber insect throws much light on the relationship of Dinapsis, it seems appropriate to describe it immediately after the appearance of Waterston's paper.

Fortunately, the fossil specis is beautifully preserved and I able to give a quite complete description.

\section{Prodinapsis gen. nov.}

$\sigma^{7}$. General form and size similar to Dinapsis Waterston. Head slightly broader than the thorax, obliquely narrowed 
behind the eyes which are large and pubescent; occipital margin raised, carinate; posterior orbits with a narrow groove; ocelli in a large triangle; vertex with a fine, but clearly impressed median line. Antennæ 14-jointed, filiform, inserted near the clypeus. Mouthparts not visible. Mesonotum about twice as broad as long; without parapsidal furrows but with a deep, complete, crenulate median furrow; inner angles of axillæ not meeting, their edges margined by deeply crenulate grooves and their inner angles connected by a crenulate groove. Propodeum coarsely reticulated and apparently without the more prominent longitudinal carinæ present in Dinapsis. Four anterior legs slender, the hind pair stout, with the femora somewhat swollen and the tibiæ enlarged apically; tibial spurs very small;hind coxæ very large; tarsal claws very small and slender, simple. Abdomen as long as the thorax, elongate oval, with seven nearly equal segments; claspers prominent, projecting downwards and curved forwards, obtusely pointed. Venter convex, the sternites almost as wide as the tergites. Fore wing with a small elongate stigma; subcostal cell broad; radial vein short, curved, leaving the cell widely open; basal half of cubitus present, but the transverse cubiti and recurrent nervure are wanting; two closed discoidal cells; basal cells indistinctly separated as the separating vein is very weak and delicate; nervulus interstitial.

Type: P. succinalis sp. nov.

Prodinapsis differs ro $\mathrm{m}$ D. napsis most strikingly in having the radial cell inocmplfete in lacking the transverse cubitus and in possessing two discoidal cells. Also the orbital groove is narrower and the axillæ do not meet at their inner angles.

Prodinapsis succinalis sp. nov. (Fig. 1).

$\sigma^{7}$. Length $2.7 \mathrm{~mm}$. Probably with the head and mesonotum black, the remainder of the thorax dark brown, the abdomen light brown and the legs piceous on the femora and tibiæ; wings hyaline and antennæ with no trace of annulation. Head coarsely shagreened, about one-half wider than long; temples two thirds as broad as the eye, occipital groove dis- 
tinctly crenulate; posterior ocelli two-thirds as far from the eye as from one another. Antennæ (Fig. 1c) slightly longer than the head and thorax; scape stout, curved; pedicel globose or but little elongated; flagellar joints of about equal length, all long and slender (probably the basal joints are slightly longer, but they cannot be viewed exactly in the proper plane). Mesonotum and scutellum shagreened; posterior edge of mesonotum straight, the suture not crenulate. Pleuræ and coxæ smooth or finely granulate; mesopleura with a crenulate line along the anterior and posterior edges. Abdominal segments of nearly

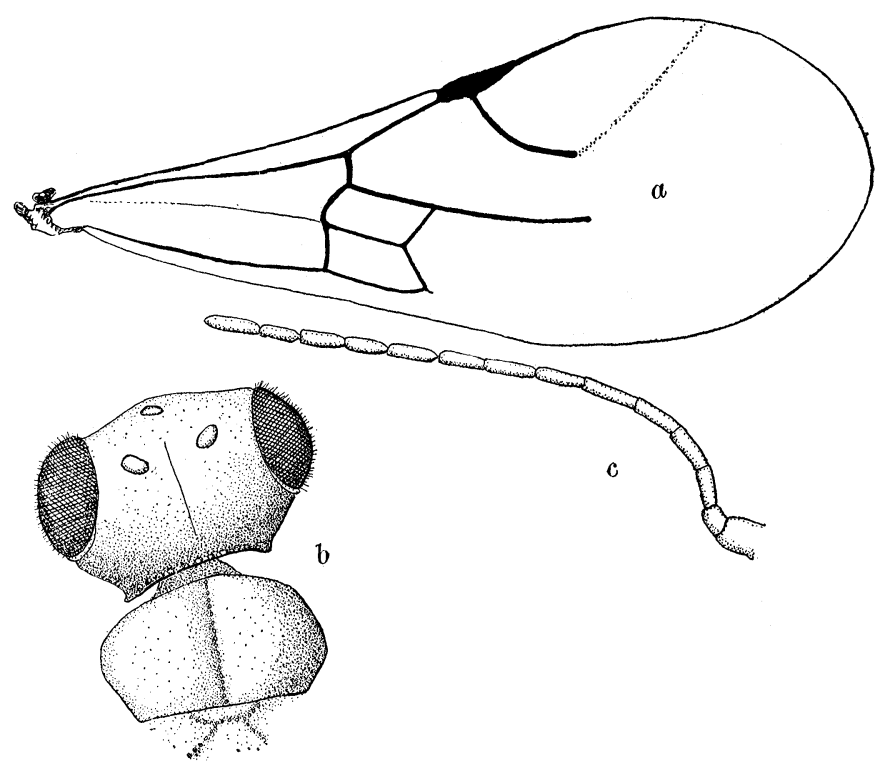

Fig. 1. Prodinapsis succinalis sp. nov. A, wing; B, head and anterior portion of thorax,

equal length, the second and also the first slightly, but not very noticeably, longer than the others; the posterior edges of the segments sinuous and slightly incised medially. Claspers almost as long as the dorsal length of the sixth segment. Wings ample, the margins with the usual short fringe of hairs, but none of the veins appear to be bristly as in Dinapsis. Venation (Fig. 1a) 
rather pale brown, but very distinct, the veins terminating abruptly as indicated; weak apical section of radial vein very indistinct and visible only in certain lights.

Type in the Amber collection of the Zoological Museum of the University of Königsberg.

Taken together the two genera exhibit a much closer affinity to Megalyra than is evident from a knowledge of either Dinapsis or Prodinapsis alone. In fact the neuration of Prodinapsis is almost identical to that of Megalyra except that the basal cells are separated by a very heavy vein in the latter and the apical part of the radius, although not vein-like, is indicated by a much more evident thickening. That the unknown female may be provided with a long ovipositor is also probable. The short and complete radial cell and absence of discoidal cells in Dinapsis give the wing a very different appearance, but the almost exactly similar, yet strikingly characteristic cephalic thoracic and abdominal structure, shows Dinapsis and Prodinapsis to be very closely related. On account of this similarity to Megalyra, it seems very doubtful whether the Dinapsidæ can be retained as a family distinct from the Megalyridæ since the differences are of a very minor nature. In both groups the head, antennæ, medially grooved mesonotum, scutellum with separated axillæ, oval sessile abdomen with more or less equal segments, long thread-like ovipositor and wing venation agree closely in form and structure; only the size is different, for Megalyra is a large insect and the other two genera are very small.

The actual relationship of the three genera is rather difficult to elucidate, since as already stated Megalyra and Prodinapsis have almost identical wings while Prodinapsis and Dinapsis are almost identical in bodily characters, but each with a wing type that cannot be derived one from the other, nor can both be derived from that of Megalyra. If the three are closely related, as seems undoubted, the ancestral form must have had a body like Dinapsis or Prodinapsis and wings with a marginal, cubital, two basal and two discoidal cells. Such an insect must have been more or less Oryssoid in many somatic and venational 
characters although perhaps only superficially similar. The median thoracic suture so pronounced in Dinapsis and Prodinapsis occurs elsewhere, so far as I am aware, only in certain Ceraphronidæ, Scelionidæ and Belytidæ of the Serphoid series where it may or may not be associated with the paired parapsidal furrows, although a few Bethylidæ and the Ampulicidæ have a median pronotal (not mesonotal) furrow. In Megalyra it is prominent and undoubtedly homologous to the one in Dinapsis.

\section{RECENT Books.}

In these lists are included titles relating entirely or directly to insects, as well as books in the related fields of biology which are of immediate interest to the Entomologist.

Folsom, $J . W$. Entomology, with Special Reference to its Ecological Aspects. pp. 502, extensively illustrated. P. Blakiston's Son \& Co. Philadelphia, 1922. A third edition of this well known and useful text, containing much new material, and needing no introduction to American entomologists.

Parker, G. H. Taste, Smell and Allied Senses in the VerTEBRATES. pp. 192, illustrated. J. B. Lippincott Co., Philadelphia $\$ 2.50$. Relates specifically to the vertebrates from the standpoint of both anatomy and physiology and presents material that the entomologist will find very useful.

Rousseau, $E$. Les LARVes ET NyMphes AQUATIQUes DES INSECTES D'Europe. vol. 1, pp. xx 967, 344 figures. J. Lebeque, Brussels. The first volume includes the Rhynchota neuropteroids and Trichoptera. A very complete and well illustrated compendium on the biology, morphology and classification of the aquatic members of these groups, with extensive bibliographical references. 

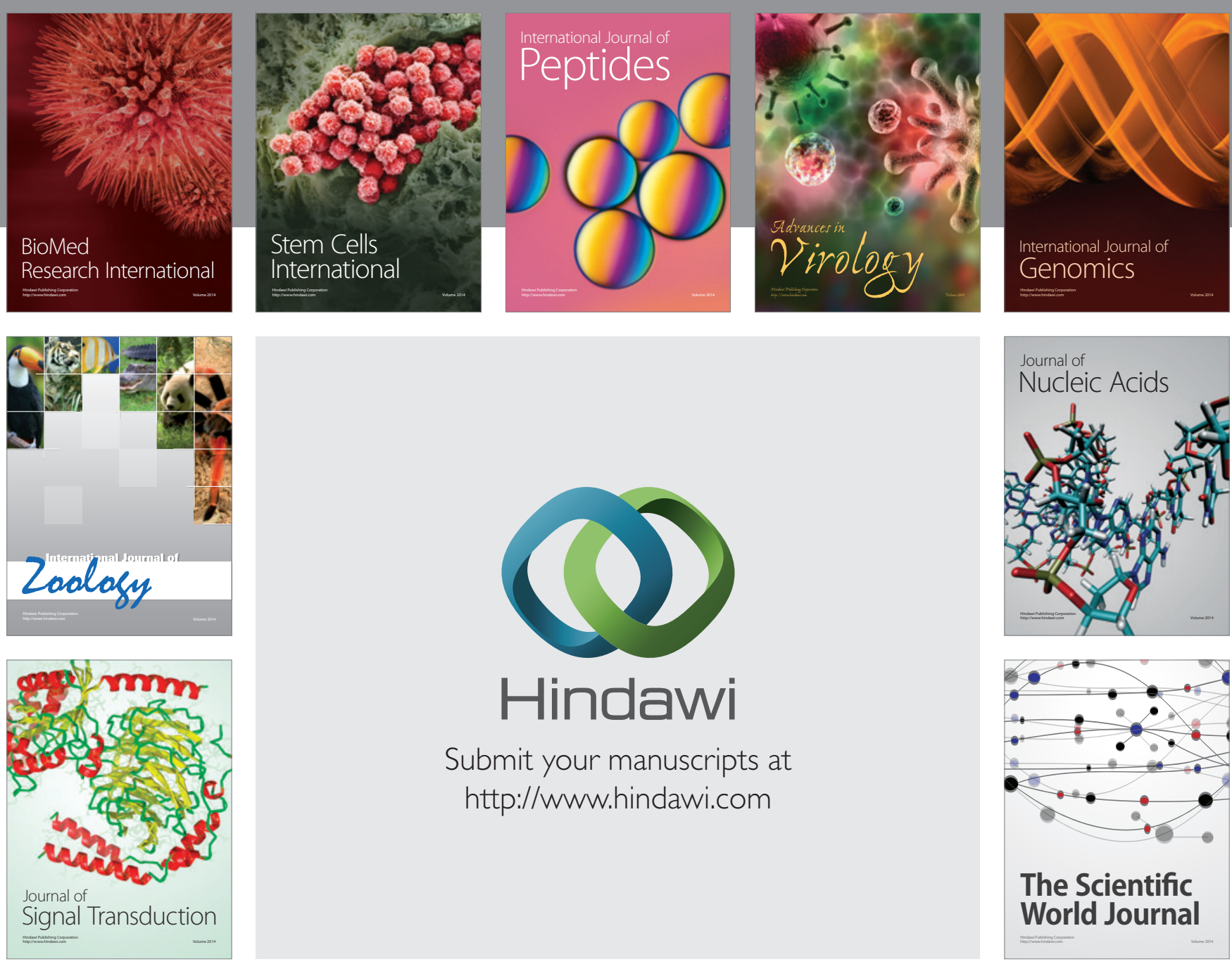

Submit your manuscripts at

http://www.hindawi.com
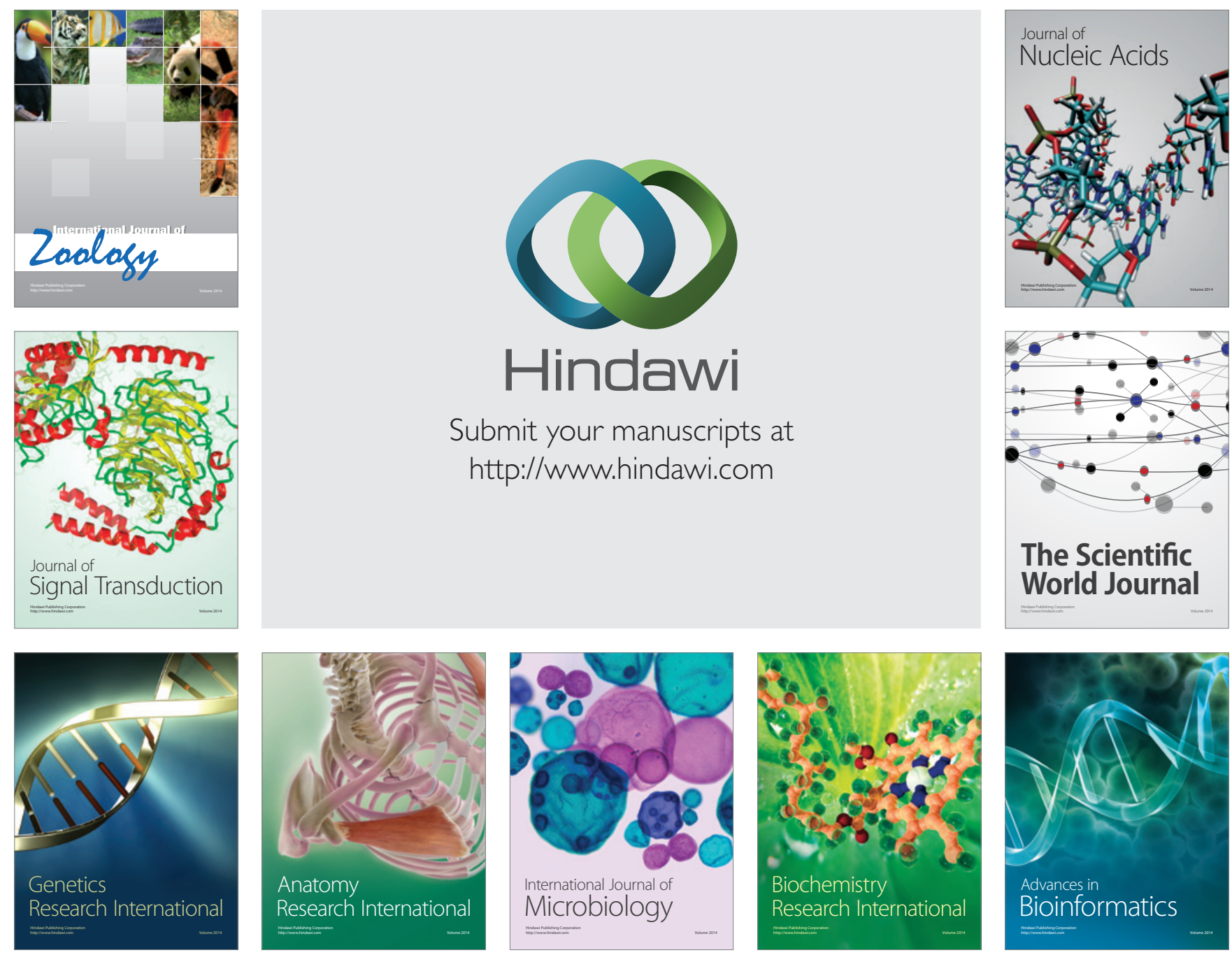

The Scientific World Journal
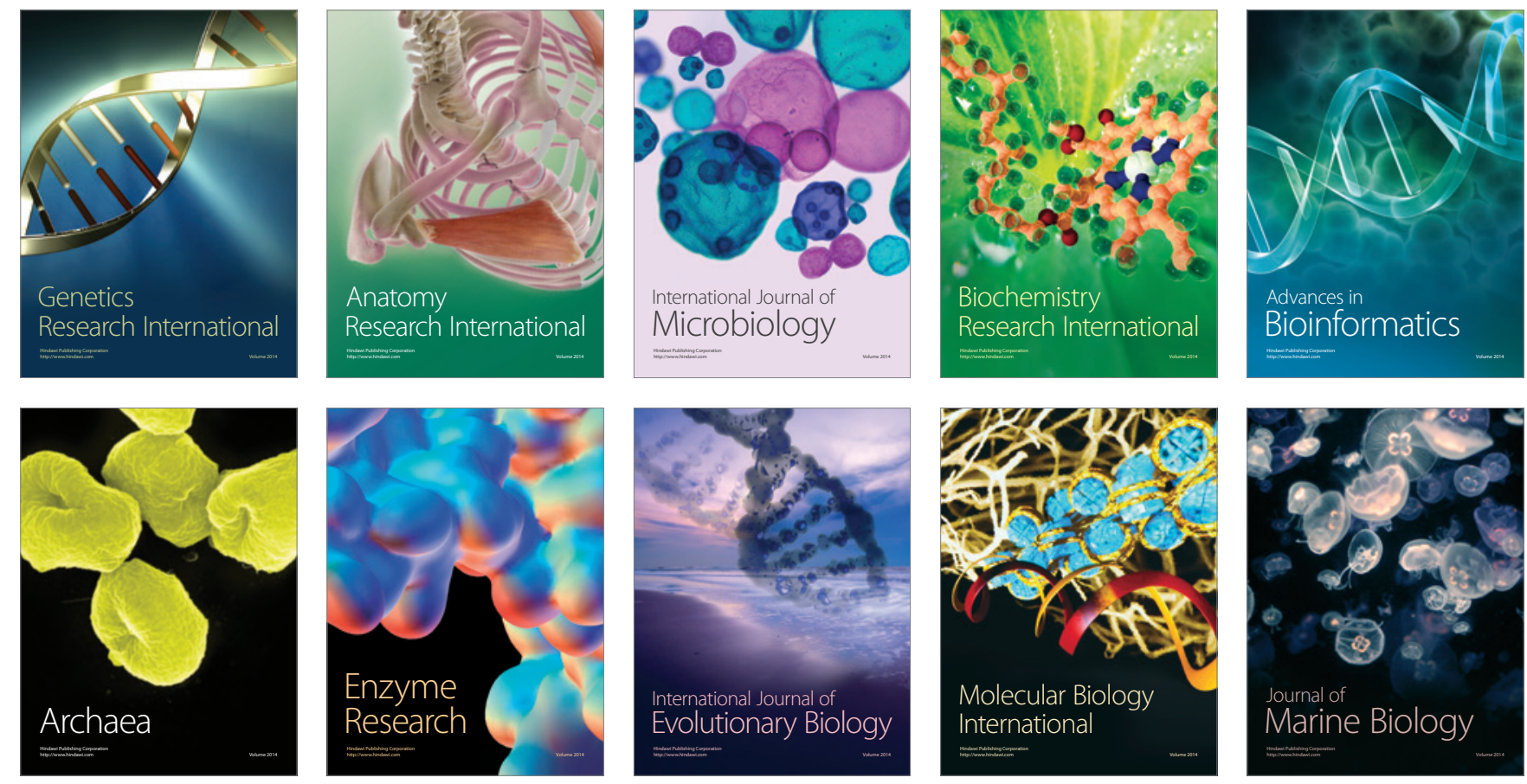